JKKP : Jurnal Kesejahteraan Keluarga dan Pendidikan

http://doi.org/10.21009/JKKP

DOI: doi.org/10.21009/JKKP.051.05

E-ISSN : 2597-4521

\title{
ANALISIS STRATEGI PEMBELAJARAN MATEMATIKA KURKULUM 2013 DALAM RANGKA MENINGKATKAN NILAI PISA MATEMATIKA
}

\author{
Moch. Sukardjo ${ }^{1, a)}$, Lipur Sugiyanta ${ }^{2, b}$ \\ Email : ${ }^{\text {a) }}$ msoekardjo@unj.ac.id, ${ }^{\text {b) lipurs@unj.ac.id }}$ \\ 1)Program Studi Pendidikan Elektronika, Fakultas Teknik, Universitas Negeri Jakarta, \\ Jl. Rawamangun Muka RT. 11/RW. 14 Jakarta Timur \\ ${ }^{2)}$ Program Studi Pendidikan Informatika, Fakultas Teknik, Universitas Negeri Jakarta, \\ Jl. Rawamangun Muka RT. 11/RW. 14 Jakarta Timur
}

\begin{abstract}
Abstrak
Mata pelajaran Matematika diberikan kepada semua peserta didik mulai dari sekolah dasar untuk membekali peserta didik dengan kemampuan berpikir logis, analitis, sistematis, kritis, dan kreatif, serta kemampuan bekerja sama. Menurut Organization for Economics Coopration and Development (OECD) tahun 2013, konsepsi literasi matematika dalam Program for International Student Assessment PISA mendukung pentingnya siswa mengembangkan pemahaman yang kuat tentang konsep-konsep matematika murni dan manfaat yang terlibat dalam eksplorasi dalam dunia abstrak matematika. Penelitian ini menghasilkan sebuah analisis trategi pembelajaran matematika Kelas IX yang mendukung kemampuan berpikir tingkat tinggi matematika (HOMT). Dua (2) bagian dari materi akan dibahas lebih fokus, yaitu (a) materi pembelajaran dan (b) strategi pembelajaran. Dengan silabus pembelajaran yang mendukung HOMT tersebut maka peluang untuk meningkatkan nilai pendidikan Matematika lebih besar, salah satu di antaranya adalah dapat disusunnya soal-soal yang menantang. Soal-soal matematika yang menantang akan memenuhi kriteria soal level tinggi (PISA memiliki tingkatan soal dari level 1 hingga level 6). HOMT mendukung pengembangan pemahaman yang kuat tentang konsep-konsep matematika murni dan bermanfaat dalam eksplorasi dalam dunia abstrak matematika. Sumber data yang digunakan dalam penyusunan buku penelitian ini adalah hasil survey PISA tahun 2006 dan 2012 dan buku kurikulum 2013 yang bersumber dari Kementerian Pendidikan dan Kebudayaan.
\end{abstract}

Kata Kunci: Matematika kelas IX, Kurikulum 2013, PISA, HOMT

\section{Analysis of Mathematics Learning Strategy of Curriculum 2013 in order to Increase Value of PISA Math}

\begin{abstract}
Mathematics courses are given to students from elementary school to higher education which equip them with logical, analytical, systematic, critical, and creative thinking skills, as well as the ability to work together. According to the Organization for Economics Cooperation and Development (OECD) year 2013, the concep of mathematical literacy in Programme for International Student Assessment (PISA) supports the importance of developing strong understanding of pure mathematical concepts and the benefits involved in exploration in the
\end{abstract}




\begin{abstract}
This research produces a Mathematics strategic learning analysis of grade IX that supports high-order mathematical thinking skills (HOMT). Two (2) parts of the materials will be discussed more focused, ie (a) learning materials and (b) learning strategies. With a learning syllabus that supports the HOMT, the opportunity to increase the value of Mathematics education is greater, one of which is formulate challenging questions. Challenging Mathematical questions will meet the criteria of high-level questions (PISA has a level of questions from level 1 to level 6). HOMT supports the development of a strong understanding of pure mathematical concepts and is useful in exploration in the abstract world of mathematics. The sources of data used in the preparation of this reseach are the results of the PISA survey in 2006 and 2012 and the 2013 curriculum book sourced from the Ministry of Education and Culture.
\end{abstract}

Keywords: Mathematics grade IX, 2013 curriculum, PISA, HOMT

\title{
PENDAHULUAN
}

Secara umum kualitas pendidikan diwarnai oleh empat kriteria yaitu: 1) kualitas awal peserta didik, 2) penggunaan dan pemilihan sumber-sumber belajar yang berkualitas, 3) proses pembelajaran, dan 4) output pendidikan. Kualitas proses pembelajaran atau keberhasilan pembelajaran pada dasarnya merupakan perubahan positif selama dan sesudah proses pembelajaran dilaksanakan. Keberhasilan ini dapat dilihat dari dua sisi yaitu dari sisi guru dan dari sisi siswa. Dari sisi guru, keberhasilan mengajar dapat dilihat dari ketepatan guru dalam memilih bahan ajar, media dan alat pembelajaran yang digunakan dalam suasana yang menggairahkan, menyenangkan, sehingga peserta didik dapat menikmati kegiatan yang memuaskan. Dari segi siswa, keberhasilan mengajar dapat dilihat dari timbulnya keinginan untuk belajar mandiri yang mengarah terjadinya peningkatan aspek kognitif, afektif dan psikomotor. Keterlibatan peserta didik secara aktif dalam proses pembelajaran dan perubahan positif yang ditimbulkan akibat dari proses belajar mengajar, dapat dilihat dari segi fisik, segi intelektual dan emosional selama berlangsungnya keinginan belajar mengajar, serta mengalami perubahan secara sadar atau tidak sadar setelah proses belajar mengajar. (Nata, 2009)

Tolok ukur tingkat kualitas pendidikan dapat dilihat dari berbagai aspek. Jika sistem manajerial yang dipergunakan bertumpu pada pendidikan sebagai suatu proses, maka berbagai langkah yang ditempuh oleh penyelenggara pendidikan formal itulah yang menentukan tolok ukur keberhasilan kinerjanya (Purwanto, 2004). Salah satu tolok ukur kualitas pendidikan yang digunakan oleh OECD (Organisation for Economic Co-operation and Development) dan dijadikan rujukan oleh pemerintah adalah hasil tes dan survey PISA (Programme for International Student Assessment).

PISA merupakan sistem ujian yang diinisasi oleh OECD, untuk mengevaluasi sistem pendidikan dari 72 negara di seluruh dunia. Setiap tiga tahun, siswa berusia 15 tahun dipilih secara acak, untuk mengikuti tes dari tiga kompetensi dasar yaitu membaca, matematika dan sains. PISA mengukur apa yang diketahui siswa dan apa yang dapat siswa lakukan (aplikasi) dengan pengetahuannya. Pengumpulan data (main survey) PISA diselenggarakan setiap tiga tahun sekali, yaitu tahun 2000, 2003, 2006, 2009, 2012 dan 2015. Tema survei digilir setiap 3 tahun, dan pada tahun 2015 fokus temanya adalah kompetensi sains. Dalam sistem pendidikan Indonesia, maka yang termasuk dalam usia ini adalah siswa-siswa SMP (kelas IX).

Tujuan keikutsertaan Indonesia dalam studi ini adalah untuk membandingkan kemampuan siswa Indonesia dengan siswa negara lain peserta studi ini. Informasi mengenai pencapaian ini akan dapat membantu pengambil kebijakan dalam menyusun kebijakan yang berhubungan dengan peningkatan mutu pendidikan di Indonesia. Di samping itu, keikutsertaan di dalam kegiatan ini dapat juga dijadikan sebagai media untuk saling bertukar informasi dan saling belajar dengan negara lain sehingga dapat dijadikan sebagai masukan untuk peningkatan program pembelajaran di Indonesia 
Kementerian Pendidikan dan Kebudayaan (Kemendikbud) merilis pencapaian nilai PISA berdasarkan survey tahun 2015, Selasa 6 Desember 2016, di Jakarta. Berdasar nilai rerata yang diperoleh, terjadi peningkatan nilai PISA Indonesia di tiga kompetensi yang diujikan. Peningkatan terbesar terlihat pada kompetensi sains, dari 382 poin pada tahun 2012 menjadi 403 poin di tahun 2015 $(+5,5 \%)$. Dalam kompetensi matematika meningkat dari 375 poin di tahun 2012 menjadi 386 poin di tahun $2015(+3 \%)$. Kompetensi membaca belum menunjukkan peningkatan yang signifikan, dari 396 di tahun 2012 menjadi 397 poin di tahun 2015 (0,3\%). Peningkatan tersebut mengangkat posisi Indonesia 6 peringkat ke atas bila dibandingkan posisi peringkat kedua dari bawah pada tahun 2012 (Kemdikbud, 2016). Melihat dari indikator utama berupa rata-rata skor pencapaian siswa-siswi Indonesia di bidang sains, matematika, dan membaca memang mengkhawatirkan, meskipun peringkat Indonesia sebenarnya naik dari hasil tes dan survey PISA 2012. Apalagi kalau dibandingkan dengan negara lain (ASEAN). Jangankan dibandingkan dengan Singapura yang menjuarai semua aspek dan indikator penilaian, dengan sesama negara Asia Tenggara yang lainpun kita tertinggal. Tercatat Vietnam yang jauh di peringkat atas dan Thailand yang juga unggul di atas Indonesia(Abdurrahman, 2003).

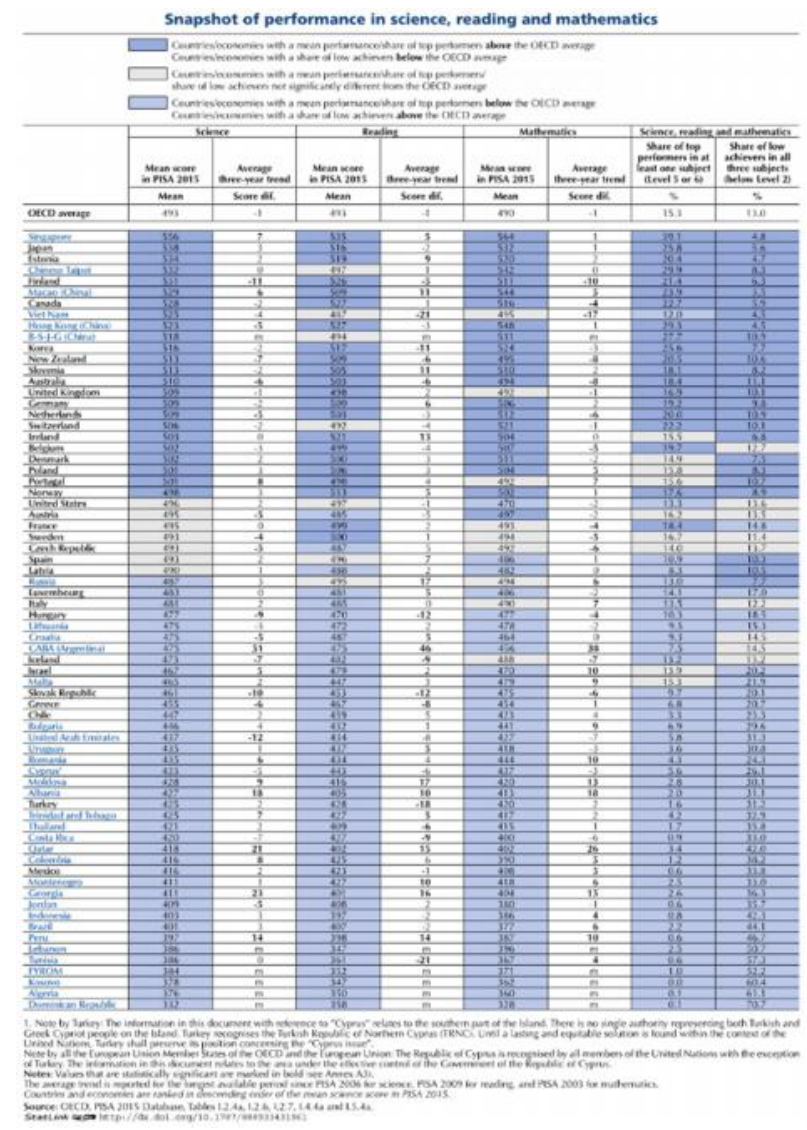

Gambar 1. Peringkat PISA negara-negara OECD atas 3 parameter: membaca, pengetahuan, dan matematika

Salah satu mata pelajaran yang dijadikan PISA sebagai tolok ukur kualitas pendidikan di suatu negara adalah matematika. Matematika merupakan bidang studi yang dipelajari oleh semua siswa dari sekolah dasar hingga menengah atas dan juga di perguruan tinggi. Matematika merupakan suatu wahana pendidikan yang mempunyai kontribusi yang berarti bagi masa depan bangsa, khususnya dalam 
mencerdaskan kehidupan bangsa. Matematika juga dapat membentuk kepribadian siswa serta mengembangkan keterampilan tertentu. Dengan belajar matematika orang dapat mengembangkan kemampuan berpikir secara matematis, logis, kritis dan kreatif yang sungguh dibutuhkan dalam kehidupan. Seperti yang diungkapkan Cornelius dalam Abdurrahman (2003) bahwa alasan perlunya belajar matematika adalah sebagai berikut: Lima alasan perlunya belajar matematika karena matematika merupakan (1) sarana berpikir yang jelas dan logis, (2) sarana untuk memecahkan masalah kehidupan sehari-hari, (3) sarana mengenal pola-pola hubungan dan generalisasi pengalaman, (4) sarana untuk mengembangkan kreativitas dan (5) sarana untuk meningkatkan kesadaran terhadap perkembangan budaya.

Indonesia berpartisipasi sejak tahun 2000 sampai sekarang. Semenjak keikutsertaan Indonesia dalam PISA, penguasaan matematika siswa kelas IX di Indonesia masih jauh tertinggal dibandingkan dengan negara lainnya. Ada beberapa faktor yang menyebabkan matematika memiliki citra negatif dimata siswa yang menyebabkan rendahnya hasil belajar, antara lain :

1. Faktor dari matematika itu sendiri

Belajar matematika menuntut kemampuan dalam berhitung, menganalisa, dan lain-lain, sedangkan kebanyakan siswa lebih memilih membaca dan menghafal daripada berhitung. Selain itu matematika bersifat hierarki, dalam arti materi matematika disusun secara sistematis, sehingga menuntut siswa untuk mengerti matematika dari materi dasar. Pada umumnya ketika siswa kurang memahami dasardasar matematika, maka siswa akan kesulitan untuk menerima pelajaran matematika ke tingkat yang lebih tinggi. Hal ini lah yang menyebabkan banyak siswa yang tidak menyukai matematika.

\section{Faktor dari guru}

Bagaimana guru menyampaikan materi dan menciptakan suasana belajar didalam kelas memiliki pengaruh besar terhadap pemahaman siswa. Pemilihan model pembelajaran yang kurang tepat juga sangat menentukan hasil belajar dan minat siswa terhadap matematika. Masih banyak guru yang menggunakan model pembelajaran konvensional untuk seluruh materi, tanpa mempertimbangkan apakah itu sesuai dengan materi tersebut. Sehingga siswa cenderung merasa bosan dalam mengikuti pelajaran tersebut. Matematika merupakan ilmu tentang logika mengenai bentuk, susunan, besaran dan konsep-konsep yang berhubungan satu dengan yang lainnya. Mengingat objek- objek penelaahan dalam matematika bersifat abstrak dan harus dipelajari sejak anak-anak, maka kegiatan pembelajaran matematika harus direncanakan. Penting bagi guru mempersiapkan bahan ajar dan menyesuaikan metode yang digunakan terhadap materi yang akan diajarkan, agar proses belajar mengajar berjalan dengan baik dan siswa memperoleh hasil belajar yang memuaskan.

\section{Faktor dari siswa}

Sugesti yang tercipta tentang matematika membuat siswa kurang termotivasi dalam menyelesaikan soal matematika, sehingga siswa kurang percaya diri untuk memulai menyelesaikan soal. Selain itu faktor-faktor yang menjadi penyebab kesuiltan belajar siswa ini berkaitan dengan kecerdasan siswa. Para guru harus meyakini bahwa setiap siswa mempunyai tingkat kecerdasan berbeda. Ada siswa yang sangat sulis menghafal sesuatu, ada yang tidak menguasai materi prasyarat, ada yang kesulitan dalam berimajinasi dan bernalar. Hal-hal yang disebutkan tadi dapat menjadi faktor penyebab kesulitan belajar pada diri siswa tersebut. Di samping itu, hal yang perlu mendapatkan perhatian adalah para siswa yang tidak memiliki pengetahuan prasyarat. Ketika sedang belajar matematika ada siswa SLTP yang tidak dapat menentukan hasil $\frac{1}{2}+\frac{1}{3}$, ataupun $1+\frac{1}{2}$. Siswa seperti itu, tentunya akan mengalami kesulitan karena materi terebut menjadi pengetahuan prasyarat untuk mempelajari matematika di tingkat berikutnya. 
Dari ketiga faktor di atas, terlihat bahwa kualitas proses pembelajaran atau keberhasilan belajar mengajar menentukan kaitan antara matematika, pendidik dan peserta didik. Siswa-siswa Indonesia belum memiliki kemampuan untuk menyelesaikan masalah non rutin atau soal-soal yang dituntut untuk berpikir lebih tinggi. Dengan demikian, salah satu hal yang perlu dikembangkan dengan optimal adalah kemampuan berpikir tingkat tinggi matematika atau yang dikenal High Order Mathematical Thinking (HOMT).

Menurut Dahlan (2009), kemampuan berpikir tingkat tinggi matematik atau High Order Mathematical Thinking (HOMT) terdiri dari kemampuan berpikir logis, kritis, sistematis, analitis, kreatif, produktif, penalaran, koneksi, komunikasi, dan pemecahan masalah matematis. Salah satu kemampuan berpikir tingkat tinggi yang diteliti oleh penulis adalah kemampuan koneksi matematis. Mariana (2011), menyatakan kemampuan koneksi matematis belum maksimal dikembangkan pada sekolah-sekolah di Indonesia. Hal ini dapat berdampak siswa sering mengalami kesulitan dalam menyelesaikan beberapa masalah dalam matematika yang notabenenya satu konsep matematika dengan konsep matematika yang lainnya saling berhubungan.

Arah kebijakan kurikulum 2013 telah menekankan pembelajaran Matematika--terutama pada penilaiannya diarahkan agar berkaitan dengan kemampuan peserta didik secara sebenarnya, berbasis kinerja peserta didik, dapat memotivasi belajar, menekankan pada kegiatan dan pengalaman belajar peserta didik, dan memberi kebebasan peserta didik untuk mengkonstruksi responnya. Untuk itu (a) pengembangan indikator dan materi pembelajaran, (b) proses pembelajaran, dan (c) evaluasi yang diberikan harus mampu mengembangkan kemampuan berpikir divergen, menekankan konteks yang mencerminkan dunia nyata, menggunakan data yang diperoleh langsung dari dunia nyata serta menggunakan berbagai cara dan instrumen. Ke-3 kemampuan tersebut harus dikuasai seorang guru sebelum terlibat dalam pembelajaran Matematika.

\section{METODOLOGI PENELITIAN}

Penelitian ini merupakan penelitian evaluasi program dengan pendekatan kualitatif yang dilaksanakan mulai bulan Februari sampai bulan November 2017. Secara umum penelitian ini mendeskripsikan konsistensi keterlaksanaan pembelajaran Kurikulum 2013 pada SMP Kelas VII.

Data yang digunakan pada kajian ini adalah data sekunder, berupa dokumen yang dikumpulkan oleh peneliti dari arsip PDSP dan laporan resmi dari laman Internet. Dokumen yang dikumpulkan dan menjadi rujukan pada kajian ini berupa:

1. Silabus Mata Pelajaran Matematika untuk Kelas IX sesuai dengan Kurikulum 2013,

2. PISA 2012 Released Mathematics Items (sample),

3. PISA 2006 Released Mathematics Items (sample).

\section{HASIL DAN PEMBAHASAN}

1. Matematika dalam konteks PISA

Menurut OECD (2013), kategori konten matematika dalam PISA terdiri dari:
a. Perubahan dan Hubungan (Change and Relationships),
b. Ruang dan Bentuk (Space and shape),
c. Bilangan (Quantity),
d. Ketidakpastian dan Data (Uncertainty and data).

Deskripsi dari keempat kategori tersebut sebagai berikut:

a. Perubahan dan hubungan (Change and Relationship)

Perubahan dan hubungan berkaitan dengan pertumbuhan organisme, musik, dan siklus musim, pola cuaca, tingkat pekerjaan dan kondisi ekonomi. Konten ini berkaitan dengan fungsi dan 
aljabar, persamaan dan pertidaksamaan, tabel dan representasi grafis, yang menjadi pusat dalam menggambarkan, memodelkan, dan menafsirkan perubahan.

b. Ruang dan bentuk (Space and Shape)

Ruang dan bentuk mencakup berbagai bentuk meliputi bentuk visual dan fisik: pola, sifat objek, posisi dan orientasi, representasi dari objek, menguraikan dari informasi visual, navigasi dan interaksi yang dinamis dengan bentuk nyata. Geometri menjadi landasan penting dalam konten ruang dan bentuk ini.

c. Bilangan (Quantity)

Bilangan berkaitan dengan hubungan bilangan dan pola bilangan. Konten bilangan melibatkan kemampuan untuk memahami ukuran, pola bilangan, dan segala sesuatu yang berhubungan dengan bilangan dalam kehidupan sehari-hari.

d. Ketidakpastian dan Data (Uncertainty and Data)

Dalam ilmu pengetahuan, teknologi dan kehidupan sehari-hari, selalu berkaitan dengan ketidakpastian karena ketidakpastian adalah hal penting dalam analisis matematis dari banyak situasi masalah. Teori peluang dan statistik serta teknik representasi data dan keterangan merupakan teori yang digunakan untuk untuk menangani hal itu.

Adapun kategori konteks matematika dalam PISA terdiri dari: 1) Pribadi (Personal), 2) Pekerjaan (Occupational), 3) Umum (Societal), 4) IImiah (Scientific). Level dalam PISA disajikan pada tabel 3.

Tabel 1. Level dalam PISA

\begin{tabular}{|c|c|}
\hline Level & Aktivitas yang dilakukan siswa \\
\hline $\begin{array}{l}\text { Level } \\
6\end{array}$ & $\begin{array}{l}\text { - Siswa dapat melakukan konseptualisasi, generalisasi dan menggunakan informasi } \\
\text { berdasarkan pada investegasi dan modeling pada situasi permasalahan yang } \\
\text { - Sompleks. } \\
\text { - Siswa dapat menghubungkan sumber informasi berbeda dengan fleksibel dan } \\
\text { menerjemahkannya. } \\
\text { - Siswa mampu berpikir dan bernalar secara matematika. } \\
\text { - Siswa dapat menerapkan pemahamannya secara mendalam disertai dengan } \\
\text { penguasaan teknis operasi matematika, mengembangkan strategi dan pendekatan } \\
\text { baru dalam menghadapi situasi yang baru. } \\
\text { - Siswa dapat merumuskan dan mengkomunikasikan dengan tepat tindakannya dan } \\
\text { merefleksikan dengan mempertimbangkan temuannya, interpretasinya, pendapatnya, } \\
\text { dan ketepatan pada situasi yang nyata. }\end{array}$ \\
\hline $\begin{array}{l}\text { Level } \\
5\end{array}$ & $\begin{array}{l}\text { - Siswa dapat mengembangkan dan bekerja dengan model pada situasi yang komplek, } \\
\text { mengidentifikasi kendala dan menjelaskan dengan tepat dugaan-dugaan. } \\
\text { - Siswa memilih, membandingkan dan mengevaluasi strategi penyelesaian masalah } \\
\text { yang sesuai ketika berhadapan dengan situasi yang rumit yang berhubungan dengan } \\
\text { model tersebut. } \\
\text { - Siswa bekerja dengan menggunakan pemikiran dan penalaran yang luas, serta secara } \\
\text { tepat menghubungkan pengetahuan dan ketrampilan matematikanya dengan situasi } \\
\text { yang dihadapi. } \\
\text { - Siswa dapat melakukan refleksi dari apa yang mereka kerjakan dan } \\
\text { mengkomunikasikan interpretasi dan penelarannya. }\end{array}$ \\
\hline $\begin{array}{c}\text { Level } \\
4\end{array}$ & $\begin{array}{l}\text { - Siswa dapat bekerja secara efektif dengan model yang tersirat dalam situasi yang } \\
\text { konkret tetapi komplek yang terdapat hambatan- hambatan atau membuat asumsi- } \\
\text { asumsi. } \\
\text { - Siswa dapat memilih dan mengabungkan representasi yang berbeda termasuk } \\
\text { - Siswy dapalkannya dan menghubungkannya dengan situasi nyata. } \\
\text { - Slasan dan pandangan yang fleksibel sesuai dengan konteks. } \\
\text { - Siswa dapat membangun dan mengkomunikasikan penjelasan dan pendapatnya } \\
\text { berdasarkan pada interpretasi, hasil dan tindakan. }\end{array}$ \\
\hline $\begin{array}{l}\text { Level } \\
3\end{array}$ & $\begin{array}{l}\text { - Siswa dapat melaksanakan prosedur dengan baik, termasuk prosedur yang } \\
\text { memerlukan keputusan secara berurutan. }\end{array}$ \\
\hline
\end{tabular}




\begin{tabular}{|c|c|}
\hline & $\begin{array}{l}\text { - Siswa dapat memilih dan menerapkan strategi memecahkan masalah yang } \\
\text { sederhana. } \\
\text { - Siswa dapat menginterpretasikan dan menggunakan representasi berdasarkan pada } \\
\text { sumber informasi yang berbeda dan mengemukakan alasannya secara langsung dari } \\
\text { yang didapat. } \\
\text { - Siswa dapat mengembangkan komunikasi sederhana melalui hasil, interpretasi dan } \\
\text { penalaran mereka. }\end{array}$ \\
\hline $\begin{array}{c}\text { Level } \\
2\end{array}$ & $\begin{array}{l}\text { - Siswa dapat menginterpretasikan dan mengenali situasi dalam konteks yang } \\
\text { memerlukan penarikan kesimpulan secara langsung. } \\
\text { - Siswa dapat memilah informasi yang relevan dari sumber tunggal dan menggunakan } \\
\text { - Senarikan kesimpulan yang tunggal. } \\
\text { - } \text { melaksanakan prosedur atau ketentuan-ketentuan yang dasar. } \\
\text { - Siswa dapat memberikan alasan secara langsung dan melakukan penafsiran secara } \\
\text { harfiah dari hasil. }\end{array}$ \\
\hline $\begin{array}{c}\text { Level } \\
1\end{array}$ & $\begin{array}{l}\text { Siswa dapat menjawab pertanyaan yang konteknya umum dimana informasi yang } \\
\text { relevan telah tersedia dan pertanyaan telah diberikan dengan jelas. } \\
\text { - Siswa dapat mengidentifikasikan informasi dan menyelesaikan prosedur rutin menurut } \\
\text { instruksi langsung pada situasi yang eksplisit. } \\
\text { - Siswa dapat melakukan tindakan secara mudah sesuai dengan stimulus yang } \\
\text { diberikan }\end{array}$ \\
\hline
\end{tabular}

Menurut Ennis (2009), Level 1 dan Level 2 termasuk berpikir kritis, sedangkan level 3, 4, 5, dan 6 termasuk berpikir kreatif. Low Ordert Thinking Skill (LOTS) banyak melibatkan cara berpikir kritis, sedangkan High Order Thinking Skill (HOTS) banyak melibatkan berpikir kritis dan berpikir kreatif (dg berpikir kreatif lebih dominan).

2. Soal Matematika PISA 2006 dan 2012

Soal-soal Matematika PISA 2006 dan 2012 (sampel soal dapat dilihat pada Lampiran 1 dan Lampiran 2), dilihat keterkaitannya dengan pola pikir Kritis (LOTS) dan pola pikir Kreatif (HOTS). Hasil kajian keterkaitannya soal PISA disajikan sebagai berikut:

Tabel 2. Bagian-Bagian Soal PISA 2006 dan 2012 dan Hubungannya dengan Berpikir Kritis/Kreatif

\begin{tabular}{|l|l|l|l|}
\hline \multicolumn{2}{|c|}{ Soal PISA 2012} & \multicolumn{2}{c|}{ Soal PISA 2006 } \\
\hline $\begin{array}{l}\text { APARTMENT } \\
\text { PURCHASE (1 } \\
\text { pertanyaan) }\end{array}$ & $\begin{array}{l}\text { Berpikir KREATIF } \\
\text { Strategi Inquiry }\end{array}$ & Farms (2 pertanyaan) & $\begin{array}{l}\text { Berpikir KREATIF } \\
\text { Strategi Inquiry }\end{array}$ \\
\hline $\begin{array}{l}\text { DRIP RATE (2 } \\
\text { pertanyaan) }\end{array}$ & $\begin{array}{l}\text { Berpikir KREATIF } \\
\text { Strategi Inquiry }\end{array}$ & Lichen (2 pertanyaan) & $\begin{array}{l}\text { Berpikir KRITIS } \\
\text { Strategi Inquiry }\end{array}$ \\
\hline CHARTS (3 pertanyaan) & $\begin{array}{l}\text { Berpikir KRITIS } \\
\text { Strategi Inquiry }\end{array}$ & Walking (2 pertanyaan) & $\begin{array}{l}\text { Berpikir KRITIS } \\
\text { Strategi Inquiry }\end{array}$ \\
\hline $\begin{array}{l}\text { SAILING SHIPS (3 } \\
\text { pertanyaan) }\end{array}$ & $\begin{array}{l}\text { Berpikir KREATIF } \\
\text { Strategi PBL }\end{array}$ & Apples (3 pertanyaan) & $\begin{array}{l}\text { Berpikir KRITIS } \\
\text { Strategi Inquiry }\end{array}$ \\
\hline SAUCE (1 pertanyaan) & $\begin{array}{l}\text { Berpikir KRITIS } \\
\text { Strategi PBL }\end{array}$ & Coins (1 pertanyaan) & $\begin{array}{l}\text { Berpikir KREATIF } \\
\text { Strategi Inquiry }\end{array}$ \\
\hline $\begin{array}{l}\text { FERRIS WHEEL (2 } \\
\text { pertanyaan) }\end{array}$ & $\begin{array}{l}\text { Berpikir KREATIF } \\
\text { Strategi Inquiry }\end{array}$ & Cubes (1 pertanyaan) & $\begin{array}{l}\text { Berpikir KREATIF } \\
\text { Strategi PBL }\end{array}$ \\
\hline $\begin{array}{l}\text { CLIMBING MOUNT FUJI } \\
\text { (3 pertanyaan) }\end{array}$ & $\begin{array}{l}\text { Berpikir KRITIS } \\
\text { Strategi PBL }\end{array}$ & $\begin{array}{l}\text { Continent Area (1 } \\
\text { pertanyaan) }\end{array}$ & $\begin{array}{l}\text { Berpikir KREATIF } \\
\text { Strategi Inquiry }\end{array}$ \\
\hline $\begin{array}{l}\text { HELEN THE CYCLIST (3 } \\
\text { pertanyaan) }\end{array}$ & $\begin{array}{l}\text { Berpikir KREATIF } \\
\text { Strategi Inquiry }\end{array}$ & $\begin{array}{l}\text { Growing Up (3 } \\
\text { pertanyaan) }\end{array}$ & $\begin{array}{l}\text { Berpikir KREATIF } \\
\text { Strategi Inquiry }\end{array}$ \\
\hline $\begin{array}{l}\text { WHICH CAR? (3 } \\
\text { pertanyaan) }\end{array}$ & $\begin{array}{l}\text { Berpikir KREATIF } \\
\text { Strategi Inquiry }\end{array}$ & Pizzas (1 pertanyaan) & $\begin{array}{l}\text { Berpikir KRITIS } \\
\text { Strategi PBL }\end{array}$ \\
\hline GARAGE (2 pertanyaan) & $\begin{array}{l}\text { Berpikir KREATIF } \\
\text { Strategi Inquiry }\end{array}$ & . Shapes (3 pertanyaan) & $\begin{array}{l}\text { Berpikir KRITIS } \\
\text { Strategi Inquiry }\end{array}$ \\
\hline
\end{tabular}




\begin{tabular}{|c|c|c|c|}
\hline \multicolumn{2}{|c|}{ Soal PISA 2012} & \multicolumn{2}{|c|}{ Soal PISA 2006} \\
\hline $\begin{array}{l}\text { REVOLVING DOOR (3 } \\
\text { pertanyaan) }\end{array}$ & $\begin{array}{l}\text { Berpikir KREATIF } \\
\text { Strategi Inquiry }\end{array}$ & $\begin{array}{l}\text { Speed of Racing Car ( } 4 \\
\text { pertanyaan) }\end{array}$ & $\begin{array}{l}\text { Berpikir KRITIS } \\
\text { Strategi Inquiry }\end{array}$ \\
\hline $\begin{array}{l}\text { MEMORY STICK ( } 2 \\
\text { pertanyaan) }\end{array}$ & $\begin{array}{l}\text { Berpikir KREATIF } \\
\text { Strategi Inquiry }\end{array}$ & . Triangles ( 1 pertanyaan) & $\begin{array}{l}\text { Berpikir KRITIS } \\
\text { Strategi PBL }\end{array}$ \\
\hline $\begin{array}{l}\text { FAULTY PLAYERS ( } 3 \\
\text { pertanyaan) }\end{array}$ & $\begin{array}{l}\text { Berpikir KRITIS } \\
\text { Strategi Inquiry }\end{array}$ & $\begin{array}{l}\text { Robberies (1 } \\
\text { pertanyaan) }\end{array}$ & $\begin{array}{l}\text { Berpikir KRITIS } \\
\text { Strategi PBL }\end{array}$ \\
\hline $\begin{array}{l}\text { ICE-CREAM SHOP ( } 3 \\
\text { pertanyaan) }\end{array}$ & $\begin{array}{l}\text { Berpikir KREATIF } \\
\text { Strategi Inquiry }\end{array}$ & Braking (5 pertanyaan) & $\begin{array}{l}\text { Berpikir KREATIF } \\
\text { Strategi Inquiry }\end{array}$ \\
\hline OIL SPILL (1 pertanyaan) & $\begin{array}{l}\text { Berpikir KREATIF } \\
\text { Strategi Inquiry }\end{array}$ & $\begin{array}{l}\text { Carpenter (1 } \\
\text { pertanyaan) }\end{array}$ & $\begin{array}{l}\text { Berpikir KRITIS } \\
\text { Strategi PBL }\end{array}$ \\
\hline $\begin{array}{l}\text { MP3 PLAYERS (3 } \\
\text { pertanyaan) }\end{array}$ & $\begin{array}{l}\text { Berpikir KRITIS } \\
\text { Strategi Inquiry }\end{array}$ & Patio (1 pertanyaan) & $\begin{array}{l}\text { Berpikir KRITIS } \\
\text { Strategi PBL }\end{array}$ \\
\hline $\begin{array}{l}\text { PENGUINS (4 } \\
\text { pertanyaan) }\end{array}$ & $\begin{array}{l}\text { Berpikir KREATIF } \\
\text { Strategi Inquiry }\end{array}$ & $\begin{array}{l}\text { Drug Concentrations (3 } \\
\text { pertanyaan) }\end{array}$ & $\begin{array}{l}\text { Berpikir KREATIF } \\
\text { Strategi PBL }\end{array}$ \\
\hline $\begin{array}{l}\text { POWER OF THE WIND ( } 4 \\
\text { pertanyaan) }\end{array}$ & $\begin{array}{l}\text { Berpikir KRITIS } \\
\text { Strategi Inquiry }\end{array}$ & $\begin{array}{l}\text { Building Blocks ( } 4 \\
\text { pertanyaan) }\end{array}$ & $\begin{array}{l}\text { Berpikir KREATIF } \\
\text { Strategi Inquiry }\end{array}$ \\
\hline $\begin{array}{l}\text { A CONSTRUCTION WITH } \\
\text { DICE ( } 1 \text { pertanyaan) }\end{array}$ & $\begin{array}{l}\text { Berpikir KREATIF } \\
\text { Strategi Inquiry }\end{array}$ & $\begin{array}{l}\text { Internet Relay Chat (2 } \\
\text { pertanyaan) }\end{array}$ & $\begin{array}{l}\text { Berpikir KREATIF } \\
\text { Strategi Inquiry }\end{array}$ \\
\hline $\begin{array}{l}\text { HOLIDAY APARTMENT } \\
\text { ( } 2 \text { pertanyaan) }\end{array}$ & $\begin{array}{l}\text { Berpikir KREATIF } \\
\text { Strategi Inquiry }\end{array}$ & $\begin{array}{l}\text { Exchange Rate ( } 3 \\
\text { pertanyaan) }\end{array}$ & $\begin{array}{l}\text { Berpikir KRITIS } \\
\text { Strategi Inquiry }\end{array}$ \\
\hline $\begin{array}{l}\text { DVD RENTAL ( } 2 \\
\text { pertanyaan) }\end{array}$ & $\begin{array}{l}\text { Berpikir KRITIS } \\
\text { Strategi Inquiry }\end{array}$ & $\begin{array}{l}\text { Reaction Time ( } 2 \\
\text { pertanyaan) }\end{array}$ & $\begin{array}{l}\text { Berpikir KREATIF } \\
\text { Strategi Inquiry }\end{array}$ \\
\hline $\begin{array}{l}\text { CABLE TELEVISION ( } 2 \\
\text { pertanyaan) }\end{array}$ & $\begin{array}{l}\text { Berpikir KRITIS } \\
\text { Strategi Inquiry }\end{array}$ & Exports (2 pertanyaan) & $\begin{array}{l}\text { Berpikir KRITIS } \\
\text { Strategi Inquiry }\end{array}$ \\
\hline $\begin{array}{l}\text { SELLING NEWSPAPERS } \\
\text { (3 pertanyaan) }\end{array}$ & $\begin{array}{l}\text { Berpikir KRITIS } \\
\text { Strategi Inquiry }\end{array}$ & $\begin{array}{l}\text { Water Tank (1 } \\
\text { pertanyaan) }\end{array}$ & $\begin{array}{l}\text { Berpikir KREATIF } \\
\text { Strategi PBL }\end{array}$ \\
\hline $\begin{array}{l}\text { CAR DRIVE (3 } \\
\text { pertanyaan) }\end{array}$ & $\begin{array}{l}\text { Berpikir KRITIS } \\
\text { Strategi Inquiry }\end{array}$ & $\begin{array}{l}\text { Coloured Candies ( } 1 \\
\text { pertanyaan) }\end{array}$ & $\begin{array}{l}\text { Berpikir KRITIS } \\
\text { Strategi PBL }\end{array}$ \\
\hline HEIGHT (3 pertanyaan) & $\begin{array}{l}\text { Berpikir KRITIS } \\
\text { Strategi Inquiry }\end{array}$ & $\begin{array}{l}\text { Science Tests (1 } \\
\text { pertanyaan) }\end{array}$ & $\begin{array}{l}\text { Berpikir KRITIS } \\
\text { Strategi PBL }\end{array}$ \\
\hline $\begin{array}{l}\text { MAKING A BOOKLET (1 } \\
\text { pertanyaan) }\end{array}$ & $\begin{array}{l}\text { Berpikir KREATIF } \\
\text { Strategi PBL }\end{array}$ & $\begin{array}{l}\text { Spring Fair (1 } \\
\text { pertanyaan) }\end{array}$ & $\begin{array}{l}\text { Berpikir KREATIF } \\
\text { Strategi PBL }\end{array}$ \\
\hline BICYCLES (3 pertanyaan) & $\begin{array}{l}\text { Berpikir KRITIS } \\
\text { Strategi Inquiry }\end{array}$ & Swing (1 pertanyaan) & $\begin{array}{l}\text { Berpikir KREATIF } \\
\text { Strategi PBL }\end{array}$ \\
\hline $\begin{array}{l}\text { SEEING THE TOWER (1 } \\
\text { pertanyaaan) }\end{array}$ & $\begin{array}{l}\text { Berpikir KREATIF } \\
\text { Strategi Inquiry }\end{array}$ & $\begin{array}{l}\text { Student Heights (1 } \\
\text { pertanyaan) }\end{array}$ & $\begin{array}{l}\text { Berpikir KRITIS } \\
\text { Strategi PBL }\end{array}$ \\
\hline & & $\begin{array}{l}\text { Payments by Area ( } 2 \\
\text { pertanyaan) } \\
\text { Bookshelves (1 } \\
\text { pertanyaan) }\end{array}$ & $\begin{array}{l}\text { Berpikir KREATIF } \\
\text { Strategi Inquiry } \\
\text { Berpikir KREATIF } \\
\text { Strategi PBL }\end{array}$ \\
\hline & & Litter (1 pertanyaan) & $\begin{array}{l}\text { Berpikir KREATIF } \\
\text { Strategi Inquiry }\end{array}$ \\
\hline & & $\begin{array}{l}\text { Earthquake (1 } \\
\text { pertanyaan) }\end{array}$ & $\begin{array}{l}\text { Berpikir KRITIS } \\
\text { Strategi PBL }\end{array}$ \\
\hline & & Choices ( 1 pertanyaan) & $\begin{array}{l}\text { Berpikir KRITIS } \\
\text { Strategi PBL }\end{array}$ \\
\hline & & $\begin{array}{l}\text { Test Scores (1 } \\
\text { pertanyaan) }\end{array}$ & $\begin{array}{l}\text { Berpikir KRITIS } \\
\text { Strategi Inquiry }\end{array}$ \\
\hline & & $\begin{array}{l}\text { Shoes for Kids ( } 1 \\
\text { pertanyaan) }\end{array}$ & $\begin{array}{l}\text { Berpikir KRITIS } \\
\text { Strategi Inquiry }\end{array}$ \\
\hline & & $\begin{array}{l}\text { Skateboard (3 } \\
\text { pertanyaan) }\end{array}$ & $\begin{array}{l}\text { Berpikir KRITIS } \\
\text { Strategi PBL }\end{array}$ \\
\hline & & . Table Tennis & Berpikir KRITIS \\
\hline
\end{tabular}




\begin{tabular}{|c|c|c|}
\hline Soal PISA 2012 & \multicolumn{2}{|c|}{ Soal PISA 2006} \\
\hline & $\begin{array}{l}\text { Tournament ( } 1 \\
\text { pertanyaan) }\end{array}$ & Strategi PBL \\
\hline & $\begin{array}{l}\text { Lighthouse (3 } \\
\text { pertanyaan) }\end{array}$ & $\begin{array}{l}\text { Berpikir KRITIS } \\
\text { Strateqi Inquiry }\end{array}$ \\
\hline & $\begin{array}{l}\text { Decreasing CO2 Levels } \\
\text { (3 pertanyaan) }\end{array}$ & $\begin{array}{l}\text { Berpikir KRITIS } \\
\text { Strategi Inquiry }\end{array}$ \\
\hline & $\begin{array}{l}\text { Twisted Building (4 } \\
\text { pertanyaan) }\end{array}$ & $\begin{array}{l}\text { Berpikir KREATIF } \\
\text { Strategi PBL }\end{array}$ \\
\hline & $\begin{array}{l}\text { Heartbeat (2 } \\
\text { pertanyaan) }\end{array}$ & $\begin{array}{l}\text { Berpikir KRITIS } \\
\text { Strategi Inquiry }\end{array}$ \\
\hline & $\begin{array}{l}\text { Space Flight (1 } \\
\text { pertanyaan) }\end{array}$ & $\begin{array}{l}\text { Berpikir KRITIS } \\
\text { Strategi Inquiry }\end{array}$ \\
\hline & Staircase (1 pertanyaan) & $\begin{array}{l}\text { Berpikir KRITIS } \\
\text { Strategi PBL }\end{array}$ \\
\hline & $\begin{array}{l}\text { Rock Concert (1 } \\
\text { pertanyaan) }\end{array}$ & $\begin{array}{l}\text { Berpikir KRITIS } \\
\text { Strategi PBL }\end{array}$ \\
\hline & $\begin{array}{l}\text { Number Cubes (1 } \\
\text { pertanyaan) }\end{array}$ & $\begin{array}{l}\text { Berpikir Kreatif } \\
\text { Strategi PBL }\end{array}$ \\
\hline & $\begin{array}{l}\text { Support for the } \\
\text { President ( } 1 \text { pertanyaan) }\end{array}$ & $\begin{array}{l}\text { Berpikir KREATIF } \\
\text { Strategi PBL }\end{array}$ \\
\hline & $\begin{array}{l}\text { Moving Walkways (1 } \\
\text { pertanyaan) }\end{array}$ & $\begin{array}{l}\text { Berpikir Kritis } \\
\text { Strategi Inquiry }\end{array}$ \\
\hline & $\begin{array}{l}\text { The Best Car (2 } \\
\text { pertanyaan) }\end{array}$ & $\begin{array}{l}\text { Berpikir KREATIF } \\
\text { Strategi Inquiry }\end{array}$ \\
\hline & $\begin{array}{l}\text { Step Pattern (1 } \\
\text { pertanyaan) }\end{array}$ & $\begin{array}{l}\text { Berpikir KREATIF } \\
\text { Strategi PBL }\end{array}$ \\
\hline & $\begin{array}{l}\text { Postal Charges (1 } \\
\text { pertanyaan) }\end{array}$ & $\begin{array}{l}\text { Berpikir Kreatif } \\
\text { Strategi Inquiry }\end{array}$ \\
\hline
\end{tabular}

${ }^{\star}$ PBL: Problem based learning

3. Analisis SKL (Standar Kompetensi Lulusan), KI-KD (Kompetensi Inti-Kompetensi Dasar), dan Silabus Matematika Kelas IX pada kurikulum 2013

LOTS dan HOTS merupakan dua kelompok yang menjadi bagian soal-soal PISA. Keduanya dapat diwujudkan melalui media dan kontek yang dapat ditemui dalam kehidupan sehari-hari. Rancangan pembelajaran Matematika Kelas IX kurikulum 2013 yang ada pada Lampiran 3 memenuhi pendekatan saintifik dengan kedalaman materi hingga tahap Prosedural dan tahap penerapan (apply).

Beberapa kata kerja yg digunakan pada tahap EKSPLORASI pada Kurikulum 2013 telah memenuhi kemampuan LOTS dan HOTS, diantaranya dapat dilihat pada tabel berikut.

Tabel 3. Kata Kerja yang Digunakan pada Silabus Matematika Kelas IX K-13

\begin{tabular}{|c|c|}
\hline LOTS & HOTS \\
\hline menulis, & menemukan, \\
menghitung, & menentukan, \\
mengukur, & manipulasi, \\
mendeskripsikan & mendemonstra \\
, mendefinisikan, & sikan, \\
menjelaskan, & menggambarka \\
membandingkan & n, membuat \\
\hline
\end{tabular}


Tabel 4. Hasil Analisa LOTS-HOTS pada Silabus Matematika Kelas IX K-13

\begin{tabular}{|c|c|c|c|}
\hline Kompetensi Dasar & Materi Pokok & Pendekatan Pembelajaran & $\begin{array}{l}\text { Analisa KATA } \\
\text { KERJA UTAMA }\end{array}$ \\
\hline $\begin{array}{l}\text { 090301 Memahami } \\
\text { sifat-sifat bilangan } \\
\text { berpangkat dan bentuk } \\
\text { akar dalam suatu } \\
\text { permasalahan } \\
090302 \text { Memahami } \\
\text { operasi aljabar yang } \\
\text { melibatkan bilangan } \\
\text { berpangkat bulat dan } \\
\text { bentuk akar } \\
\text { 090408 Membuat dan } \\
\text { menyelesaikan model } \\
\text { matematika dari } \\
\text { berbagai permasalahan } \\
\text { nyata }\end{array}$ & $\begin{array}{l}\text { Pangkat dan } \\
\text { akar }\end{array}$ & $\begin{array}{l}\text { EKSPLORASI } \\
\text { Pangkat dan akar } \\
\text { - Menulis bentuk perpangkatan } \\
\text { dari bentuk perkalian berulang } \\
\text { dan menghitung hasil } \\
\text { berbagai perpangkatan } \\
\text { bilangan } \\
\text { - Menyusun atau membuat } \\
\text { serta mendeskripsikan aturan } \\
\text { dari pola/barisan bilangan } \\
\text { berpangkat dan barisan } \\
\text { bangun datar yang } \\
\text { bersesuaian } \\
\text { - Menjelaskan, mendeskripsikan } \\
\text { dan menemukan melalui } \\
\text { pengamatan sifat } \\
\text { perpangkatan dengan satu, } \\
\text { perpangkatan dengan nol dan } \\
\text { perpangkatan dengan bilangan } \\
\text { negative } \\
\text { - Mendeskripsikan dan } \\
\text { menuliskan hasil pengukuran } \\
\text { yang sangat besar atau sangat } \\
\text { kecil dalam bentuk notasi } \\
\text { ilmiah, untuk menuliskan masa } \\
\text { electron, masa bakteri, masa } \\
\text { matahari, masa bumi dsb } \\
\text { - Menulis bentuk akar dari } \\
\text { bentuk pembagian berulang } \\
\text { dan sebagai kebalikan dari } \\
\text { perpangkatan serta } \\
\text { menghitung hasil berbagai } \\
\text { penarikan akar bilangan, } \\
\text { dilanjutkan dengan } \\
\text { mendefinisikan pengertian } \\
\text { akar dan notasi penulisannya } \\
\text { - Menjelaskan, mendeskripsikan } \\
\text { dan menemukan melalui } \\
\text { pengamatan sifat-sifat operasi } \\
\text { aljabar, manipulasi matematika } \\
\text { dengan bilangan berpangkat } \\
\text { - Berlatih menentukan hasil } \\
\text { penarikan akar, hasil } \\
\text { perpangkatan, notasi ilmiah, } \\
\text { solusi suatu masalah, } \\
\text { prosedur penyederhanaan } \\
\text { bentuk pangkat dan akar atau } \\
\text { unsur lainnya berkaitan } \\
\text { dengan perpangkatan dan } \\
\text { bentuk akar }\end{array}$ & $\begin{array}{l}\text { Berpikir KRITIS } \\
\text { (LOTS): menulis, } \\
\text { menghitung, } \\
\text { mendeskripsikan, } \\
\text { mendefinisikan. } \\
\text { Berpikir KREATIF } \\
\text { (HOTS): } \\
\text { menemukan, } \\
\text { menentukan. }\end{array}$ \\
\hline $\begin{array}{l}090303 \text { Menganalisis } \\
\text { sifat-sifat fungsi kuadrat }\end{array}$ & $\begin{array}{l}\text { Fungsi dan } \\
\text { persamaan }\end{array}$ & $\begin{array}{l}\text { EKSPLORASI } \\
\text { Fungsi kuadrat }\end{array}$ & \\
\hline
\end{tabular}




\begin{tabular}{|c|c|c|c|}
\hline Kompetensi Dasar & Materi Pokok & Pendekatan Pembelajaran & $\begin{array}{c}\text { Analisa KATA } \\
\text { KERJA UTAMA }\end{array}$ \\
\hline $\begin{array}{l}\text { ditinjau dari koefisien } \\
\text { dan determinannya } \\
090401 \text { Menyelesaikan } \\
\text { permasalahan nyata } \\
\text { yang berkaitan dengan } \\
\text { fungsi kuadrat }\end{array}$ & kuadrat & $\begin{array}{l}\text { - Memberikan berbagai contoh } \\
\text { kejadian, peristiwa, situasi } \\
\text { atau fenomena alam dan } \\
\text { aktifitas sosial sehari-hari yang } \\
\text { berkaitan dengan fungsi } \\
\text { kuadrat } \\
\text { - Mendiskusikan dan } \\
\text { menjelaskan ciri dan sifat dari } \\
\text { variabel, koefisien, konstata } \\
\text { dan derajat dari suatu fungsi } \\
\text { kuadrat, dan menggambarkan } \\
\text { sketsa serta mendeskripsikan } \\
\text { bentuk grafik dan titik } \\
\text { puncaknya } \\
\text { - Mendiskusikan, menjelaskan } \\
\text { dan melakukan manipulasi } \\
\text { matematika tertentu untuk } \\
\text { menyederhanakan atau } \\
\text { mengubah fungsi kuadrat ke } \\
\text { bentuk kuadrat sempurna } \\
\text { Melakukan percobaan atau } \\
\text { mendemonstrasikan untuk } \\
\text { menemukan rumus sumbu } \\
\text { simetri dan diskriminan dari } \\
\text { fungsi kuadrat, dilanjutkan } \\
\text { dengan menggambar dan } \\
\text { menjelaskan karakteristik } \\
\text { berbagai sketsa grafik fungsi } \\
\text { kuadrat untuk berbagai nilai } \\
\text { koefisien dan diskriminan } \\
\text { - Berlatih menentukan nilai } \\
\text { fungsi kuadrat, titik potong } \\
\text { dengan sumbu koordinat, } \\
\text { sumbu simetri, titik puncak, } \\
\text { koefisien dan diskriminan, } \\
\text { sifat-sifat dan sketsa grafik, } \\
\text { ataupun unsur lainnya } \\
\text { berkaitan dengan fungsi } \\
\text { kuadrat }\end{array}$ & $\begin{array}{l}\text { Berpikir KRITIS } \\
\text { (LOTS): } \\
\text { menjelaskan. } \\
\text { BERPIKIR KREATIF } \\
\text { (HOTS): manipulasi, } \\
\text { mendemonstrasikan, } \\
\text { menentukan. }\end{array}$ \\
\hline $\begin{array}{l}\text { 090304 Memahami } \\
\text { perbandingan bertingkat } \\
\text { dan persentase, serta } \\
\text { mendeskripsikan } \\
\text { permasalahan } \\
\text { menggunakan tabel, } \\
\text { grafik, dan persamaan } \\
\text { 090402 Menggunakan } \\
\text { konsep perbandingan } \\
\text { untuk menyelesaikan } \\
\text { masalah nyata } \\
\text { mencakup perbandingan } \\
\text { bertingkat dan } \\
\text { persentase dengan } \\
\text { menggunakan tabel, }\end{array}$ & Perbandingan & $\begin{array}{l}\text { EKSPLORASI } \\
\text { Perbandingan/rasio/proporsi } \\
\text { - Membahas, mendeskripsikan } \\
\text { dan menjelaskan pecahan } \\
\text { biasa, pembilang, penyebut } \\
\text { dan representasinya ke dalam } \\
\text { berbagai bentuk gambar, serta } \\
\text { kaitan dan penulisannya dalam } \\
\text { bentuk rasio, perbandingan } \\
\text { atau proporsi } \\
\text { - Membahas dan } \\
\text { mendeskripsikan strategi } \\
\text { mengubah suatu } \\
\text { perbandingan ke dalam bentuk } \\
\text { nilai perbandingan bulat paling }\end{array}$ & $\begin{array}{l}\text { Berpikir KRITIS } \\
\text { (LOTS): } \\
\text { mendeskripsikan, } \\
\text { membandingkan. } \\
\text { BERPIKIR KREATIF } \\
\text { (HOTS): } \\
\text { menentukan. }\end{array}$ \\
\hline
\end{tabular}




\begin{tabular}{|c|c|c|c|}
\hline Kompetensi Dasar & Materi Pokok & Pendekatan Pembelajaran & $\begin{array}{c}\text { Analisa KATA } \\
\text { KERJA UTAMA }\end{array}$ \\
\hline $\begin{array}{l}\text { grafik, dan persamaan } \\
090403 \text { Menyelesaikan } \\
\text { permasalahan dengan } \\
\text { menaksir besaran yang } \\
\text { tidak diketahui } \\
\text { menggunakan berbagai } \\
\text { modifikasi aljabar dan } \\
\text { aritmatika }\end{array}$ & & $\begin{array}{l}\text { sederhana } \\
\text { - Menentukan nilai } \\
\text { perbandingan bertingkat atau } \\
\text { persentase dari kuantitas } \\
\text { benda dengan kuantitas benda } \\
\text { lainnya dalam suatu kumpulan } \\
\text { benda, atau suatu } \\
\text { ukuran/besaran dengan } \\
\text { ukuran/besaran lainnya di } \\
\text { bidang aritmetika social, } \\
\text { pengukuran (geometri, sains) } \\
\text { dan masalah lainnya } \\
\text { - Membahas, mendeskripsikan } \\
\text { dan menjelaskan ciri atau } \\
\text { karakteristik serta menentukan } \\
\text { nilai perbandingan yang } \\
\text { bersifat seharga/linear atau } \\
\text { berbalik nilai/tidak senlai dari } \\
\text { dua besaran yang memiliki } \\
\text { hubungan fungsional dan } \\
\text { disajikan dalam bentuk table, } \\
\text { grafik dan persamaan } \\
\text { Berlatih menentukan nilai } \\
\text { perbandingan, kuantitas benda } \\
\text { tertentu, ataupun kuantitas } \\
\text { keseluruhan benda, table, } \\
\text { grafik dan persamaan, } \\
\text { termasuk penerapannya di } \\
\text { bidang aritmetika social, } \\
\text { pengukuran (geometri, sains) } \\
\text { dan masalah lainnya berkaitan } \\
\text { dengan perbandingan }\end{array}$ & \\
\hline $\begin{array}{l}090305 \text { Menentukan } \\
\text { orientasi dan lokasi } \\
\text { benda dalam koordinat } \\
\text { kartesius serta } \\
\text { menentukan posisi relatif } \\
\text { terhadap acuan tertentu }\end{array}$ & $\begin{array}{l}\text { Koordinat } \\
\text { Cartesius }\end{array}$ & $\begin{array}{l}\text { EKSPLORASI } \\
\text { Sistem koordinat: denah dan } \\
\text { peta } \\
\text { - membahas, menjelaskan, dan } \\
\text { mendeskripsikan melalui } \\
\text { contoh kedudukan suatu titik } \\
\text { dan bangun datar serta } \\
\text { menggambarkannya dalam } \\
\text { system koordinat Cartesius } \\
\text { - Membaca, menjelaskan dan } \\
\text { mengukur suatu benda, letak } \\
\text { atau jarak suatu tempat pada } \\
\text { denah/peta manual atau peta } \\
\text { digital untuk menentukan arah } \\
\text { dan ukuran sebenarnya } \\
\text { benda, posisi atau jarak suatu } \\
\text { tempat dalam system } \\
\text { koordinat } \\
\text { - Menggambar berdasarkan } \\
\text { hasil deskripsi denah/peta } \\
\text { posisi dan arah dari suatu } \\
\text { benda dan letak suatu tempat }\end{array}$ & $\begin{array}{l}\text { Berpikir KRITIS } \\
\text { (LOTS): } \\
\text { menjelaskan, } \\
\text { mendeskripsikan, } \\
\text { mengukur. } \\
\text { BERPIKIR KREATIF } \\
\text { (HOTS): } \\
\text { menggambar. }\end{array}$ \\
\hline
\end{tabular}




\begin{tabular}{|c|c|c|c|}
\hline \multirow[t]{2}{*}{ Kompetensi Dasar } & Materi Pokok & Pendekatan Pembelajaran & $\begin{array}{l}\text { Analisa KATA } \\
\text { KERJA UTAMA }\end{array}$ \\
\hline & & $\begin{array}{l}\text { pada system koordinat dengan } \\
\text { skala yang sesuai } \\
\text { - Membaca, menjelaskan } \\
\text { denah/peta kontur sederhana } \\
\text { secara manual atau digital } \\
\text { untuk menentukan arah, } \\
\text { ukuran, posisi, jarak dan } \\
\text { ketinggian suatu daerah dalam } \\
\text { system koordinat }\end{array}$ & \\
\hline $\begin{array}{l}\text { 090201 Menunjukkan } \\
\text { perilaku ingin tahu } \\
\text { dalam melakukan } \\
\text { aktivitas di rumah, } \\
\text { sekolah, dan } \\
\text { masyarakat sebagai } \\
\text { wujud implementasi } \\
\text { mempelajari sifat-sifat } \\
\text { segitiga sebangun dan } \\
\text { kongruen } \\
\text { 090306 Memahami } \\
\text { konsep kesebangunan } \\
\text { dan kekongruenan } \\
\text { geometri melalui } \\
\text { pengamatan } \\
\text { 090405 Menyelesaikan } \\
\text { permasalahan nyata } \\
\text { hasil pengamatan yang } \\
\text { terkait penerapan } \\
\text { kesebangunan dan } \\
\text { kekongruenan }\end{array}$ & $\begin{array}{l}\text { Relasi antar } \\
\text { bangun }\end{array}$ & $\begin{array}{l}\text { EKSPLORASI } \\
\text { Melakukan pekerjaan secara } \\
\text { tekun, sabar, teliti dan sungguh- } \\
\text { sungguh untuk menyelidiki sifat- } \\
\text { sifat dalam konsep matematika, } \\
\text { serta secara khusus dalam } \\
\text { menyelidiki sifat-sifat segitiga } \\
\text { sebangun dan kongruen, sbb: } \\
\text { - Mengidentifikasi dan } \\
\text { mendeskripsikan persamaan } \\
\text { dan perbedaan permukaan } \\
\text { benda-benda dan gambar atau } \\
\text { kejadian yang memiliki bentuk } \\
\text { sama } \\
\text { - Mendeskripsikan, } \\
\text { menjelaskan sifat, ciri dan } \\
\text { persamaan dan perbedaan } \\
\text { benda dengan permukaan } \\
\text { yang sebangun dan kongruen } \\
\text { berdasarkan hasil pengamatan } \\
\text { - Membuat model, } \\
\text { menggambar atau melukis } \\
\text { bangun-bangun datar } \\
\text { sebangun dan kongruen } \\
\text { dengan berbagai cara dan } \\
\text { posisi } \\
\text { - Menentukan atau } \\
\text { menggambar bangun datar } \\
\text { yang sebangun dan kongruen } \\
\text { dengan bangun lain } \\
\text { - Berlatih menentukan sisi, } \\
\text { sudut, dan ukurannya, atau } \\
\text { unsur lainnya berkaitan } \\
\text { dengan kesebangunan } \\
\text { - Menjelaskan atau } \\
\text { mendeskripsikan masalah ke } \\
\text { dalam bahasa sendiri, } \\
\text { diagram, gambar, ilustrsi yang } \\
\text { lebih sederhana, jelas dan } \\
\text { lengkap } \\
\text { - Membahas, mengidentifikasi, } \\
\text { dan menentukan konsep } \\
\text { serta mengorganisasi data dan } \\
\text { memilih informasi yang relevan } \\
\text { berkaitan dengan masalah }\end{array}$ & $\begin{array}{l}\text { Berpikir KRITIS } \\
\text { (LOTS): } \\
\text { mengidentifikasi, } \\
\text { mendeskripsikan. } \\
\text { BERPIKIR KREATIF } \\
\text { (HOTS): membuat, } \\
\text { menggambar, } \\
\text { menentukan, } \\
\text { merumuskan, } \\
\text { memilih. }\end{array}$ \\
\hline
\end{tabular}




\begin{tabular}{|c|c|c|c|}
\hline Kompetensi Dasar & Materi Pokok & Pendekatan Pembelajaran & $\begin{array}{l}\text { Analisa KATA } \\
\text { KERJA UTAMA }\end{array}$ \\
\hline & & $\begin{array}{l}\text { kesebangunan dan kongruen } \\
\text { dengan merepresentasikan } \\
\text { secara matematis, melalui } \\
\text { model atau melalui diagram } \\
\text { - Menyusun, membuat atau } \\
\text { merumuskan model atau } \\
\text { kalimat matematika yang } \\
\text { tepat, lengkap dan cukup } \\
\text { berdasarkan masalah } \\
\text { kesebangunan dan kongruen } \\
\text { - Menggunakan, memanfaatkan } \\
\text { dan memilih algoritma atau } \\
\text { prosedur operasi serta } \\
\text { manipulasi matematika yang } \\
\text { tepat dalam menyelesaikan } \\
\text { model dari masalah berkaitan } \\
\text { kesebangunan dan kongruen } \\
\text { - Menentukan dan menafsirkan } \\
\text { solusi atau penyelesaian } \\
\text { masalah serta memberikan } \\
\text { alasan kebenaran solusi } \\
\text { berkaitan dengan } \\
\text { kesebangunan dan kongruen }\end{array}$ & \\
\hline $\begin{array}{l}090307 \text { Menentukan } \\
\text { luas selimut dan volume } \\
\text { tabung, kerucut, dan } \\
\text { bola } \\
090308 \text { Menaksir dan } \\
\text { mengitung luas } \\
\text { permukaan bangun } \\
\text { datar dan bangun ruang } \\
\text { yang tidak beraturan } \\
\text { dengan menerapkan } \\
\text { kombinasi geometri } \\
\text { dasarnya }\end{array}$ & $\begin{array}{l}\text { Luas dan } \\
\text { volume }\end{array}$ & $\begin{array}{l}\text { EKSPLORASI } \\
\text { - Membahas, membentuk atau } \\
\text { menyusun berbagai jaring- } \\
\text { jaring tabung, kerucut, dan } \\
\text { bola (yang tertutup atau tanpa } \\
\text { tutup beberapa bagian) } \\
\text { - Membahas, menjelaskan } \\
\text { strategi dan melakukan } \\
\text { percobaan untuk menemukan } \\
\text { dan menghitung luas } \\
\text { permukaan serta volume } \\
\text { tabung, kerucut, dan bola atau } \\
\text { berdasarkan konep luas dan } \\
\text { volume bangun prisma dan } \\
\text { limas. } \\
\text { - Berlatih menentukan luas, } \\
\text { volume ataupun unsur lainnya } \\
\text { yang berkaitan dengan tabung, } \\
\text { kerucut, dan bola } \\
\text { - Membahas, menggambar } \\
\text { atau membuat sketsa bangun } \\
\text { ruang beraturan atau bangun } \\
\text { geometri dasar yang memiliki } \\
\text { kesamaan atau kemiripan } \\
\text { ukuran dengan bangun ruang } \\
\text { tidak beraturan (bersisi } \\
\text { lengkung ataupun yang tidak } \\
\text { lengkung) } \\
\text { - Membahas, menjelaskan } \\
\text { strategi menghitung luas dan } \\
\text { volume bangun geometri dasar }\end{array}$ & $\begin{array}{l}\text { Berpikir KRITIS } \\
\text { (LOTS): } \\
\text { menjelaskan. } \\
\text { BERPIKIR KREATIF } \\
\text { (HOTS): } \\
\text { menggambar, } \\
\text { menentukan. }\end{array}$ \\
\hline
\end{tabular}




\begin{tabular}{|c|c|c|c|}
\hline Kompetensi Dasar & Materi Pokok & Pendekatan Pembelajaran & $\begin{array}{c}\text { Analisa KATA } \\
\text { KERJA UTAMA }\end{array}$ \\
\hline & & $\begin{array}{l}\text { sebagai cara untuk menaksir } \\
\text { luas dan volume bangun ruang } \\
\text { tidak beraturan sisi lengkung/ } \\
\text { tidak lengkung } \\
\text { - Berlatih menentukan luas, } \\
\text { volume ataupun unsur lainnya } \\
\text { yang berkaitan dengan bangun } \\
\text { ruang tidak beraturan bersisi } \\
\text { lengkung ataupun yang tidak } \\
\text { lengkung }\end{array}$ & \\
\hline $\begin{array}{l}\text { 090203 Menunjukkan } \\
\text { perilaku jujur dan } \\
\text { bertanggung jawab } \\
\text { sebagai wujud } \\
\text { implementasi kejujuran } \\
\text { dalam melaporkan data } \\
\text { pengamatan } \\
\text { 090309 Menentukan } \\
\text { peluang suatu kejadian } \\
\text { sederhana secara } \\
\text { empirik dan teoritik } \\
\text { 090311 Menentukan } \\
\text { nilai rata-rata, median, } \\
\text { dan modus dari berbagai } \\
\text { jenis data } \\
\text { 090312 Memahami } \\
\text { teknik penyajian data } \\
\text { dari dua variabel } \\
\text { menggunakan tabel dan } \\
\text { berbagai jenis grafik } \\
\text { masalah nyata serta } \\
\text { menentukan hubungan } \\
\text { antar variabel untuk } \\
\text { mengambil kesimpulan } \\
\text { 090313 Memahami } \\
\text { konsep ruang sampel } \\
\text { dan menentukan } \\
\text { anggota melalui } \\
\text { percobaan } \\
\text { 090406 Mengumpulkan, } \\
\text { mengolah, } \\
\text { menginterpretasi, dan } \\
\text { menampilkan data hasil } \\
\text { pengamatan dalam } \\
\text { bentuk tabel dan } \\
\text { berbagai grafik serta } \\
\text { mengidentifikasi } \\
\text { hubungan antar variabel } \\
\text { serta mengambil } \\
\text { kesimpulan } \\
\text { 090407 Menerapkan } \\
\text { prinsip-prinsip peluang } \\
\text { untuk menyelesaikan } \\
\text { masalah nyata } \\
\end{array}$ & $\begin{array}{l}\text { Peluang dan } \\
\text { statistika }\end{array}$ & $\begin{array}{l}\text { EKSPLORASI } \\
\text { - Membahas, mendiskusikan } \\
\text { dan menjelaskan perbedaan } \\
\text { melalui berbagai contoh sifat } \\
\text { atau karakteristik kejadian } \\
\text { acak atau random, } \\
\text { independen, saling lepas, atau } \\
\text { bersyarat serta berbagai factor } \\
\text { yang menyebabkan kejadian } \\
\text { bersifat tidak acak, tidak } \\
\text { independen, atau tidak saling } \\
\text { lepas } \\
\text { Menjelaskan, } \\
\text { mendeskripsikan dan } \\
\text { menemukan probabilitas atau } \\
\text { peluang empiric, menjelaskan } \\
\text { melalui contoh untuk } \\
\text { merumuskan konsep peluang } \\
\text { secara teoritik, serta } \\
\text { membentuk diagram pohon, } \\
\text { tabulasi/table, dan pendaftaran } \\
\text { untuk merumuskan dan } \\
\text { menafsirkan sifat peluang } \\
\text { Berlatih menentukan peluang } \\
\text { kejadian acak, peluang } \\
\text { kejadian yang dipengaruhi } \\
\text { faktor-faktor kualitatif, } \\
\text { pengalaman dengan situasi } \\
\text { yang serupa atau intuisi } \\
\text { tertentu, ataupun unsur lainnya } \\
\text { berkaitan dengan peluang, } \\
\text { serta peluang kejadian } \\
\text { independen, bersyarat secara } \\
\text { sederhana } \\
\text { - Membaca, mendeskripsikan } \\
\text { dan menjelaskan atau } \\
\text { melakukan interpretasi sajian } \\
\text { dari tingkat } \\
\text { kecenderungan/tendensi } \\
\text { sentral/ ukuran pemusatan } \\
\text { data menggunakan statistic } \\
\text { tertentu: rata-rata, median, } \\
\text { modus, serta memberikan } \\
\text { persamaan dan perbedaan arti }\end{array}$ & $\begin{array}{l}\text { Berpikir KRITIS } \\
\text { (LOTS): } \\
\text { menjelaskan, } \\
\text { mendeskripsikan. } \\
\text { BERPIKIR KREATIF } \\
\text { (HOTS): } \\
\text { menemukan, } \\
\text { merumuskan, } \\
\text { menentukan, } \\
\text { memutuskan, } \\
\text { merancang, } \\
\text { menafsirkan. }\end{array}$ \\
\hline
\end{tabular}




\begin{tabular}{|c|c|c|c|}
\hline Kompetensi Dasar & Materi Pokok & Pendekatan Pembelajaran & $\begin{array}{r}\text { Analisa KATA } \\
\text { KERJA UTAMA }\end{array}$ \\
\hline & & 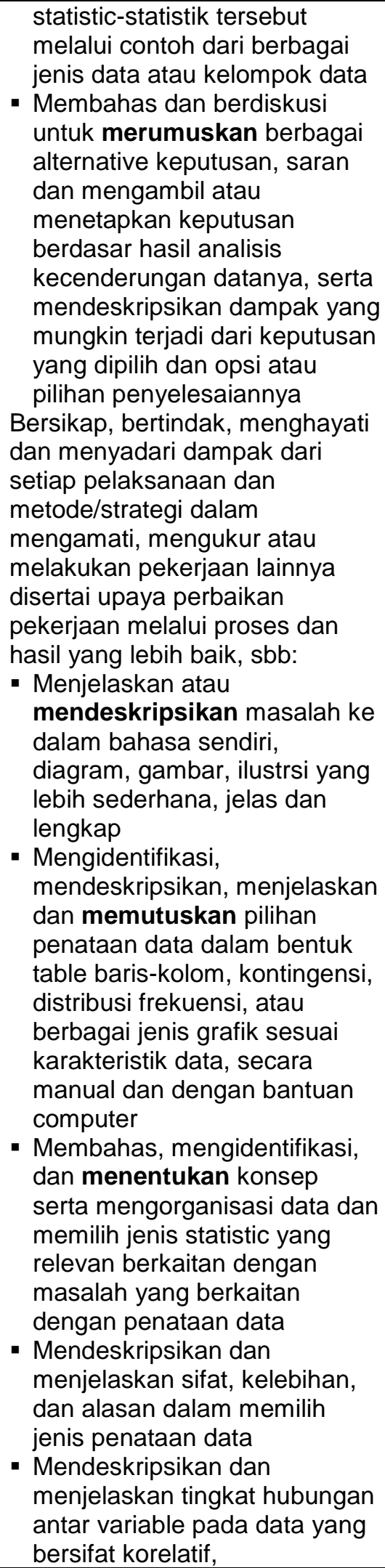 & \\
\hline
\end{tabular}




\begin{tabular}{|c|c|c|c|}
\hline Kompetensi Dasar & Materi Pokok & Pendekatan Pembelajaran & $\begin{array}{r}\text { Analisa KATA } \\
\text { KERJA UTAMA }\end{array}$ \\
\hline & & 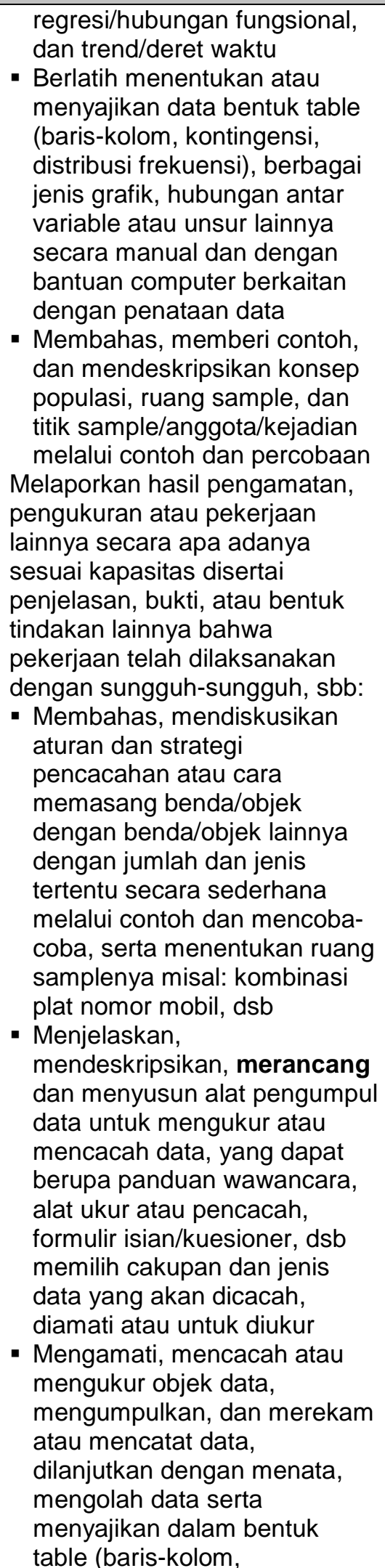 & \\
\hline
\end{tabular}




\begin{tabular}{|c|c|c|c|}
\hline Kompetensi Dasar & Materi Pokok & Pendekatan Pembelajaran & $\begin{array}{r}\text { Analisa KATA } \\
\text { KERJA UTAMA }\end{array}$ \\
\hline & & 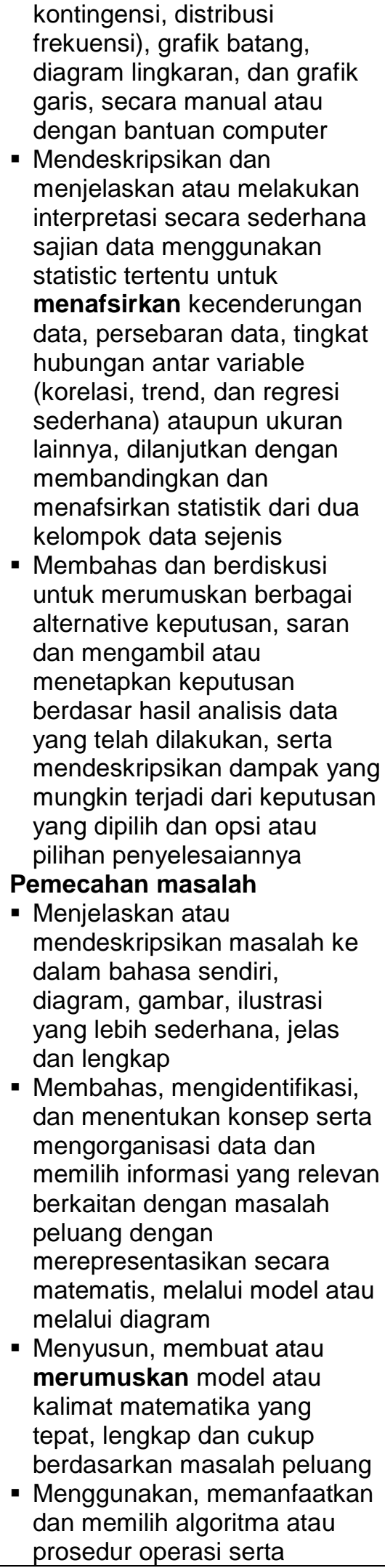 & \\
\hline
\end{tabular}




\begin{tabular}{|c|c|c|c|}
\hline Kompetensi Dasar & Materi Pokok & Pendekatan Pembelajaran & $\begin{array}{l}\text { Analisa KATA } \\
\text { KERJA UTAMA }\end{array}$ \\
\hline & & $\begin{array}{l}\text { manipulasi matematika yang } \\
\text { tepat dalam menyelesaikan } \\
\text { model dari masalah berkaitan } \\
\text { peluang } \\
\text { - Menentukan dan menafsirkan } \\
\text { solusi atau penyelesaian } \\
\text { masalah serta memberikan } \\
\text { alasan kebenaran solusi } \\
\text { berkaitan dengan peluang }\end{array}$ & \\
\hline $\begin{array}{l}\text { 090202 Menunjukkan } \\
\text { perilaku konsisten dan } \\
\text { teliti dalam melakukan } \\
\text { aktivitas di rumah, } \\
\text { sekolah, dan } \\
\text { masyarakat sebagai } \\
\text { wujud implementasi } \\
\text { mempelajari barisan, } \\
\text { deret aritmetika dan } \\
\text { geometri } \\
\text { 090310 Menerapkan } \\
\text { pola dan generalisasi } \\
\text { untuk membuat prediksi } \\
\text { 090314 Memilih strategi } \\
\text { dan aturan-aturan yang } \\
\text { sesuai untuk } \\
\text { memecahkan suatu } \\
\text { permasalahan } \\
\text { 090404 Menggunakan } \\
\text { pola dan generalisasi } \\
\text { untuk menyelesaikan } \\
\text { masalah nyata serta } \\
\text { menemukan masalah } \\
\text { baru }\end{array}$ & $\begin{array}{l}\text { Pola, barisan } \\
\text { dan deret }\end{array}$ & $\begin{array}{l}\text { EKSPLORASI } \\
\text { Bersikap, bertindak sesuai } \\
\text { aturan dan prosedur matematika } \\
\text { dalam melakukan pekerjaan } \\
\text { matematika, dan secara khusus } \\
\text { dalam bekerja serta bersikap, } \\
\text { bertindak dan melakukan } \\
\text { pekerjaan secara cermat, hati- } \\
\text { hati dan sungguh-sungguh } \\
\text { dalam melakukan pekerjaan } \\
\text { matematika, dan secara khusus } \\
\text { dalam bekerja dengan pola, } \\
\text { barisan dan deret pola, barisan } \\
\text { dan deret, sbb: } \\
\text { - Mendeskripsikan dan } \\
\text { menjelaskan dengan berbagai } \\
\text { contoh kejadian, peristiwa, } \\
\text { situasi atau fenomena alam } \\
\text { dan aktifitas sosial sehari-hari } \\
\text { yang memiliki pola tertentu, } \\
\text { serta memberi alasan dari ciri, } \\
\text { sifat atau karakteristik pola } \\
\text { tersebut } \\
\text { - Mendiskusikan dan } \\
\text { menjelaskan cara, strategi, } \\
\text { metode untuk membuat } \\
\text { generalisasi beberapa sifat } \\
\text { dalam matematika melalui } \\
\text { pendekatan percobaan, } \\
\text { pengamatan pola, atau secara } \\
\text { deduktif sederhana } \\
\text { - Membahas, mendiskusikan } \\
\text { dan menjelaskan pola, barisan } \\
\text { dan deret melalui contoh dari } \\
\text { pola/barisan bilangan, } \\
\text { geometris, ataupun fenomena } \\
\text { lainnya, serta strategi untuk } \\
\text { melakukan prediksi dalam } \\
\text { menentukan polanya } \\
\text { - Membahas, mengidentifikasi, } \\
\text { dan menentukan konsep } \\
\text { serta mengorganisasi data dan } \\
\text { memilih informasi yang relevan } \\
\text { berkaitan dengan masalah } \\
\text { dengan merepresentasikan } \\
\end{array}$ & $\begin{array}{l}\text { Berpikir KRITIS } \\
\text { (LOTS): } \\
\text { menjelaskan. } \\
\text { BERPIKIR KREATIF } \\
\text { (HOTS): } \\
\text { merumuskan, } \\
\text { menentukan, } \\
\text { memanfaatkan. }\end{array}$ \\
\hline
\end{tabular}




\begin{tabular}{|c|c|c|c|}
\hline Kompetensi Dasar & Materi Pokok & Pendekatan Pembelajaran & $\begin{array}{l}\text { Analisa KATA } \\
\text { KERJA UTAMA }\end{array}$ \\
\hline & & $\begin{array}{l}\text { secara matematis, melalui } \\
\text { model atau melalui diagram } \\
\text { - Menyusun, membuat atau } \\
\text { merumuskan model atau } \\
\text { kalimat matematika yang } \\
\text { tepat, lengkap dan cukup } \\
\text { berdasarkan masalah } \\
\text { - Menggunakan, } \\
\text { memanfaatkan dan memilih } \\
\text { algoritma atau prosedur } \\
\text { operasi serta manipulasi } \\
\text { matematika yang tepat dalam } \\
\text { menyelesaikan model } \\
\text { - Mengidentifikasi, menjelaskan } \\
\text { atau mendeskripsikan masalah } \\
\text { yang merupakan dan berkaitan } \\
\text { dengan pola bilangan, pola } \\
\text { geometris, dan fenomena } \\
\text { sehari-hari serta membuat } \\
\text { generalisasi untuk } \\
\text { merumuskan masalah } \\
\text { baru/lainnya } \\
\text { - Membahas, mengidentifikasi, } \\
\text { dan menentukan aturan serta } \\
\text { mengorganisasi data dan } \\
\text { memilih informasi yang relevan } \\
\text { berkaitan dengan masalah } \\
\text { pola bilangan, pola geometris, } \\
\text { dan fenomena sehari-hari } \\
\text { dengan merepresentasikan } \\
\text { secara matematis, melalui } \\
\text { model atau melalui diagram } \\
\text { - Menggunakan, } \\
\text { memanfaatkan dan memilih } \\
\text { algoritma atau prosedur } \\
\text { operasi serta manipulasi } \\
\text { matematika yang tepat dalam } \\
\text { menyelesaikan model dari } \\
\text { masalah pola bilangan, pola } \\
\text { geometris, dan fenomena } \\
\text { sehari-hari }\end{array}$ & \\
\hline
\end{tabular}

4. Kelompok LOTS (Lower Order Thinking Skills (LOTS)) dan HOTS (Higher Order Thinking Skills (HOTS)) pada Matematika Kurikulum 2013

Dari bahasan Matematika Kelas IX yang telah dianalisa pada Tabel 6, hampir semua materi telah dirancang untuk memenuhi LOTS dan HOTS. Rincian analisis pada tahap Eksplorasi pada materi Matematika Kurikulum 2013 yang memenuhi LOTS dan HOTS diberikan pada tabel berikut.

Tabel 5. LOTS dan HOTS Matematika Kelas IX K-13

\begin{tabular}{|c|c|}
\hline Materi & LOTS/HOTS Tahap Eksplorasi \\
\hline Pangkat dan akar & LOTS (5)/HOTS (2): dominan berpikir KRITIS \\
\hline $\begin{array}{c}\text { Fungsi dan persamaan } \\
\text { kuadrat }\end{array}$ & LOTS (2)/HOTS (3): dominan berpikir KREATIF \\
\hline Perbandingan & LOTS (4)/HOTS (1): dominan berpikir KRITIS \\
\hline
\end{tabular}




\begin{tabular}{|c|c|}
\hline Materi & LOTS/HOTS Tahap Eksplorasi \\
\hline Koordinat Cartesius & LOTS (3)/HOTS (1): dominan berpikir KRITIS \\
\hline Relasi antar bangun & LOTS (4)/HOTS (6): dominan berpikir KREATIF \\
\hline Luas dan volume & LOTS (2)/HOTS (4): dominan berpikir KREATIF \\
\hline Peluang dan statistika & LOTS (10)/HOTS (13): dominan berpikir KREATIF \\
\hline Pola, barisan dan deret & LOTS (4)/HOTS (6): dominan berpikir KREATIF \\
\hline
\end{tabular}

Dari pemaparan pada bagian 3 dan 4 diatas, dapat dilihat bahwa apabila target kurikulum 2013 dipadankan dengan soal-soal PISA maka antara keduanya sudah sesuai/mendukung. Dengan demikian, apabila secara desain pelajaran Matematika pada Kurikulum 2013 sudah sesuai dengan tipe soal Matematika PISA, maka dengan nilai rerata Matematika PISA yang belum maksimal, aspek yang perlu diperhatikan BUKAN pada materi Matematika-nya, namun lebih kepada pelaksanaan pembelajaran Matematika di lapangan (sekolah/rumah).

Persoalan pencapaian standar PISA berada pada Guru sebagai ujung tombak. Selain itu, faktor lain yang mempengaruhi pelaksanaan pembelajaran Matematika sesuai Kurikulum 2013 adalah:

1. Guru Matematika

Apakah Guru-Guru pada tingkat SMP/MTs mampu memberikan/memfasilitasi pembelajaran Matematika yang terstruktur mulai LOTS sampai dengan HOTS. Hal ini tidak dapat ditawar lagi.

UKG yang telah dilaksanakan diharapkan mendukung untuk penguasaan konsep Matematika. Selain penguasaan materi Matematika, pengusaaan strategi pembelajaran oleh guru yang mendukung SLC (student learning centre) dan yang dapat mendukung HOTS juga tidak kalah penting. Hal ini hanya dapat diraih melalui ketrampilan proses (kegiatan inti) yang terpola dan berkelanjutan. Guru harus memahami langkah-langkah penggunaan strategi pembelajaran dengan benar. Strategi pembelajaran yang sesuai dengan tuntutan HOST, diantaranya adalah INQUIRY dan PROBLEM BASED LEARNING. Keduanya juga memenuhi pendekatan saintifik yang digunakan pada Kurikulum 2013.

2. Guru Bahasa Indonesia

Untuk mencapai target kurikulum 2013 yang menuntut HOTS, maka siswa harus mampu memahami, menguasai, dan mengintrepretasikan/memaknai kalimat yang digunakan pada soal Matematika secara benar. Ada banyak kata penting Matematika yang tersurat dan tersirat (tidak langsung ditemukan dengan mambaca). Siswa memiliki kemampuan tersebut hanya jika penguasaan bahasa/soal dilakukan secara berkelanjutan dan sejak dini (dari kelas VII).

3. Siswa

Siswa harus dilatih untuk memiliki ketahan-malangan yang tinggi (tidak mudah menyerah). Pada beberapa sekolah, sejak kelas VII, siswa sudah diidentifikasi mana yang memiliki IQ yang diatas ratarata dan siswa-siswa yang dibawahnya. Anak-anak dengan kemampuan tinggi tersebut diberikan pengayaan dengan soal-soal yang lebih bervariasi. Pola seperti ini dikenal dengan identifikasi anak berbakat. Anak-anak dengan kelompok inilah yang sebenarnya sudah siap dituntut untuk berpikir tingkat tinggi (HOTS).

4. Kepala sekolah

Manajemen kepemimpinan kepala sekolah harus mendukung. Harus ada keinginan dan langkahlangkah konkret dari sekolah untuk mencapai target PISA.

5. Fasilitas Sekolah

Fasilitas (alat peraga) yang mendukung strategi pembelajaran inquiry dan problem based learning harus lengkap. Budaya pembelajaran di kelas perlu diubah untuk memberikan keleluasaan siswa berpendapat dan beragumentasi dalam rangka menciptakan sikap kritis. Dengan memberikan kesempatan kepada siswa untuk menyampaikan ide baru atau inovasi lain meskipun tidak sama dari kebiasaan yang sudah ada dapat menciptakan kreatifitas siswa. Kemudian menghargai setiap hasil yang dikerjakan siswa (salah atau benar).

Perubahan budaya belajar tersebut dapat membentuk pembelajaran yang menyenangkan. Harapannya adalah bagaimana semua siswa akan mengikuti kesenangan belajar matematika.

6. Orang tua

Dukungan orang tua terhadap kegiatan siswa, baik di sekolah maupun di rumah tetap berpengaruh besar. Orang tua harus mendukung dalam bentuk motivasi, penyediaan berbagai macam sumber belajar selama di rumah, dan berperan aktif mendampingi belajar anak. 


\section{KESIMPULAN}

Dari pembahasan diatas, terdapat dua hal penting untuk disimpulkan, yaitu:

1. Dalam rangka untuk mencapai target perbaikan rangking PISA, tuntutan Matematika pada Kurikulum 2013 sudah cukup tinggi/sesuai dengan tipe soal PISA. Analisa atas materi Matematika pada Kurikulum 2013 berikut dengan indikator pemenuhan kompetensi-nya sudah memenuhi tingkat berpikir LOTS dan HOTS. Pemetaan soal-soal PISA tahun 2006 dan 2012 didominasi dengan soalsoal HOTS yang harus dijawab setelah memahami data dan interpretasi yang ada pada soal (inquiry/discovery).

2. Strategi pembelajaran yang sesuai diterapkan pada pembelajaran Matematika Kelas IX sesuai Kurikulum 2013 adalah Inquiry dan Problem Based Learning.

Sejauh mana penguasaan Guru terhadap strategi pembelajaran Matematika dengan fokus kepada siswa (student centered learning) dan penerapan strategi pembelajaran Inquiry dan Problem Based Learning untuk mendukung pemahaman LOTS sampai dengan HOTS sebaiknya menjadi fokus kajian berikutnya. Diperlukan sampling untuk mendapatkan data apakah Guru memahami langkah-langkah menggunakan strategi pembelajaran yang dipilihnya.

\section{DAFTAR PUSTAKA}

E. B. Johnson. 2002. Contextual Teaching and Learning: What it is and why it's here to stay. Corwin Press,Inc. California.

J. A. Dahlan. 2009. Pengembangan model computer based e-learning untuk meningkatkan kemampuan high order mathematical thinking siswa SMA. LPPM UPI. Bandung.

G. Watson and E. M. Glaser. 1980. Critical Thinking Appraisal. Harcourt Brace Jovanovich, Inc. New York.

Hakim. 2016. Analisis Gambaran Kompetensi Guru Terhadap Prestasi Belajar Siswa SMP Pada Ujian Nasional Tahun 2015 Provinsi Daerah Istimewa Yogyakarta. Pusat Data dan Statistik Pendidikan dan Kebudayaan. Jakarta.

M. Abdurrahman. 2003. Pendidikan Bagi Anak Berkesulitan Belajar. Rineka Cipta. Jakarta.

Nata. 2009. Perspektif Islam Tentang Strategi Pembelajaran. Kencana Prenada Media Group. Jakarta.

N. Purwanto. 2004. Psikologi Pendidikan. Remaja Rosdakarya. Bandung

OECD. 2012. OECD Programme for International Student Assessment 2012. OECD. Westat,

OECD. 2006. OECD Programme for International Student Assessment 2006. OECD. Westat.

P. P. P. Kemdikbud. 2016. Penilaian yang Berkualitas untuk Pendidikan yang Berkualitas [Online]. Available:http://litbang.kemdikbud.go.id/pengumuman/Mengenal\%20Puspendik\%205\%20Jan \%202015-2.pdf. [Accessed 07 Feb 2016].

P. K. d. Perbukuan. 2015. Buku Guru Matematika Kelas IX SMP/MTs. Kementerian Pendidikan dan Kebudayaan. Jakarta.

R. H. Ennis. 1985. Critical Thinking. University of Illinois. New Jersey: Prentice Hall.

R. W. Weisberg. 2006. Expertise and Reason in Creative Thinking: Evidence from Case Studies and the Laboratory. Cambridge University Press. Cambridge.

S. Mariana. 2011. Penerapan pendekatan kontekstual dengan pemberian tugas mind map setelah pembelajaran terhadap peningkatan kemampuan koneksi matematis siswa SMP.

S. Krulik and J. A. Rudnick. 1995. The New Sourcebook for Teaching Reasoning and Problem Solving in Elementary School. Allyn \& Bacon. Needham Heights.

Sardiman. 1987. Interaksi dan Motivasi Belajar Mengajar. Rajawali Pers. Jakarta.

Suwarma and D. Mayadiana. 2009. Suatu Alternatif Pembelajaran Kemampuan Berpikir Kritis 
Matematika. Cakrawala Maha Karya. Jakarta

T. Gustiningsi. 2015. Pengembangan Soal Matematika Model Pisa Untuk Mengetahui Kemampuan Berpikir Kritis Matematis Siswa Kelas VII. Jurnal Pendidikan Matematika JPM RAFA, vol. Vol.1, no. No.1, September 2015.

T. Y. E. Siswono. 2016. Berpikir Kritis dan Berpikir Kreatif sebagai Fokus Pembelajaran Matematika in Seminar Nasional Matematika Dan Pendidikan Matematika (1st SENATIK). Semarang. 